Acta Universitatis Nicolai Copernici • Pedagogika XXVIII/2012

Nauki Humanistyczno-Społeczne • Zeszyt 405

Marzenna Zaorska

Uniwersytet Mikołaja Kopernika w Toruniu

\title{
Rola I Miejsce PEDAgoga SPECJALNEgo W KREOWANIU DZIAEALNOŚCI EDUKACYJNO-TERAPEUTYCZNEJ
}

\section{WPROWADZENIE}

Ta przestrzeni wieków i rozwoju ludzkości zauważamy specyficz1 ne oraz charakterystyczne dla poszczególnych epok cechy, które można odnieść zarówno do obszaru funkcjonowania społecznego, mentalnego, jak i naukowo-cywilizacyjnego, a także do obszaru szeroko ujętej edukacji dzieci i młodzieży. Zmiany na nowe wyjątkowo intensywnie pojawiają się na przełomie XIX i XX wieku i towarzyszą ludzkości do dzisiaj, ale już z bardziej wszechobecnym wpływem na życie indywidualne i zbiorowe, i to zarówno w pozytywnym, jak i niestety w negatywnym wymiarze.

Na niewątpliwe podkreślenie w kontekście szybkości, jakości oraz intensywności rozwoju cywilizacyjnego i społecznego zasługuje druga połowa XX oraz pierwsze dziesięciolecie XXI wieku. Pojawia się bowiem nie tylko nieobecny wcześniej rozwój technik komunikacyjnych i medialnych na duże odległości, ale też następuje poważna zmiana w podejściu do świata wartości, sensu życia i jego istoty oraz nastawień do znaczenia pomocy i wsparcia udzielanego osobom marginalizowanym, odrzucanym, mniej sprawnym, funkcjonującym w niesprzyjających warunkach materialnych czy rozwojowo-wychowawczych. Stąd 
pojawiają się tendencje do bardziej globalnego, holistycznego, ale też zindywidualizowanego ujmowania ludzkiego istnienia, ze szczególnym uwzględnieniem istnienia odbiegającego od ogólnie przyjętych standardów normy lub niemieszczącego się w owych standardach, albo nienadążającego za zmianami naukowo-technicznymi, mentalnymi i społecznymi. W gronie osób marginalizowanych lub zagrożonych sugerowaną marginalizacją, gdzieś tam zagubionych, nienadążających, odbiegających od standardów wyznaczonych etapem rozwoju cywilizacji znajdują się zapewne osoby z niepełnosprawnością oraz ich najbliższe środowisko życia i wychowania. Stąd pojawia się ogromna rola systemu edukacji i specjalnego wsparcia oraz ludzi w tym systemie pracujących - pedagogów specjalnych, terapeutów, psychologów i innych specjalistów.

Na przestrzeni dziejów ludzkości stosunek do osób niepełnosprawnych, ich problemów życiowych i możliwości rozwoju był zróżnicowany, na ogół miał charakter izolacyjno-stygmatyzujący i był połączony z etykietowaniem, a nawet wyrokowaniem o posiadanych predyspozycjach, indywidualnych zasobach, perspektywach przyszłości i prawach na współistnienie w społeczeństwie obywatelskim.

Mimo obecności osób niepełnosprawnych w strukturach społecznych od zarania dziejów ludzkości, dopiero tak naprawdę XX wiek przyniósł nastawienia zorientowane na celową i intensywną opiekę, rehabilitację, edukację, wsparcie w dążeniach do samodzielności oraz integrację społeczną.

Szczególnie ostatnie dziesięciolecia postrzegane mogą być jako te, które charakteryzują się dodatnimi intencjami w uznawaniu praw osób z niepełnosprawnością: do rozwoju zgodnego z możliwościami pomocy, poszanowania godności, autonomii osobowej i społecznej. W obszarze jakości życia osoby niepełnosprawnej zauważono nadrzędność wpływów środowiskowych nad wpływami uszkodzonej organiki.

Stąd nowe podejście do podmiotu zainteresowań współczesnej pedagogiki specjalnej, zarówno teorii, jak i praktyki, zorientowane nie tyle na mechaniczne trenowanie umiejętności niezbędnych w przyszłym życiu (chociaż niewątpliwe jest ono znaczące), ile na stworzeniu osobie niepełnosprawnej warunków do decydowania o sobie, o własnym życiu, do samorealizacji i zdobycia wymaganego przygotowania do pełnienia różnych ról społecznych w dorosłości. 
Aby człowiek z niepełnosprawnością mógł podjąć różne możliwe i wymagane role społeczne w perspektywie dorosłości, musi osiągnąć określony poziom funkcjonowania osobowościowego, fizycznego i społecznego. Wobec powyższego do zadań instytucji powołanych na rzecz pomocy w rozwoju dzieciom, młodzieży, dorosłym (służba zdrowia, edukacja, pomoc społeczna, organizacje pozarządowe), a także różnych środowisk - rodzina, instytucje kształcenia i wychowania, instytucje kultury i rekreacji, środowisko lokalne (mikro), środowisko kraju (makro), należy poznanie możliwości podmiotów znajdujących się pod ich wpływem i określenie racjonalnych strategii realizacji zadań związanych z autonomizacją i samorealizacją tych podmiotów. Tak ujęte cele może zrealizować jedynie specjalista wykraczający w swojej pracy poza powszechnie przyjęte i często „utarte” przez lata standardy - twórczy/kreatywny, innowacyjny.

\section{Profesjonalizm, Kompetencje, PREDYSPOZYCJE PEDAGOGA SPECJALNEGO PRACUJĄCEGO Z UCZNIEM NIEPELNOSPRAWNYM}

Zawód pedagoga specjalnego należy do szczególnych i wyjątkowych. Poza przygotowaniem teoretycznym/merytorycznym o charakterze interdyscyplinarnym, wymaga licznych kompetencji praktycznych, predyspozycji wewnętrznych - osobowych (w tym charakterologicznych i empatycznych). Innymi słowy obejmuje wielość elementów, które można pogrupować $\mathrm{w}$ trzech ogólnych obszarach: profesjonalizm, predyspozycje i kompetencje. Każdy z wymienionych obszarów może współdecydować i rzeczywiście współdecyduje o jakości pracy pedagoga specjalnego, efektywności podejmowanych przez niego działań i, co najistotniejsze, o jakości przyszłego życia wychowanków, także szczególnych z powodu posiadanych możliwości, obecnych ograniczeń i ich psychospołecznych konsekwencji. Stąd od pedagoga specjalnego oczekuje się współcześnie nie tylko formalnej realizacji wynikających z wykonywanego zawodu zadań, ale też kreatywnego/twórczego podejścia do każdego planowanego, a zatem urzeczywistnianego w odniesieniu do procesu edukacyjno-terapeutycznego w faktycznym działaniu. 
W Słowniku języka polskiego możemy znaleźć następującą interpretację terminu „kompetencja”: „zakres uprawnień, pełnomocnictw (...); zakres czyjejś wiedzy, umiejętności lub odpowiedzialności (...)"1. Za kompetentnego uznaje się człowieka uprawnionego do realizacji określonych działań, do wydawania decyzji; mającego kwalifikacje do wypowiadania sądów, opinii, ocen; autorytatywnego, miarodajnego ${ }^{2}$.

Z kolei predyspozycje są wrodzonymi skłonnościami, dyspozycjami do czegoś. Mówimy między innymi o predyspozycjach psychicznych, fizycznych, muzycznych, aktorskich itd. Natomiast pojęcie „kreatywność”, inaczej kreacyjność, to po prostu twórczość, bycie twórczym w postępowaniu, działaniu, myśleniu, ale też - co może być swoistym zagrożeniem $\mathrm{w}$ interpretacji, a właściwie nadinterpretacji tego terminu - to opieranie się na twórczości, własnej fantazji, a nie na obserwacji życia; kreacja zaś oznacza, między innymi - sposób odtworzenia przez „aktora” jakiejś postaci, wybitne, oryginalne zagranie roli ${ }^{3}$. Określenie innowacyjności/innowacji (łac. innovatio) można ująć jako wprowadzenie/wprowadzanie czegoś nowego; rzecz nowo wprowadzona; nowość, reforma (co oznacza, że innowacja może być np. nowością, reformą - a nowości, reformy, jak wszyscy wiemy, nie zawsze mają i/lub mogą mieć ukierunkowania dodatnie, „in plus”) 4 .

Profesjonalizm polega nie tylko na uprawianiu jakiejś dziedziny zawodowo, na przechodzeniu w realizowanych działaniach od amatorstwa do profesjonalizmu, ale jest sztuką w dużej mierze opartą na zadatkach wrodzonych. Profesjonalizm nabywamy stopniowo. By profesjonalizm był prawdziwym profesjonalizmem musi wzrastać na bazie predyspozycji wewnętrznych, głosu serca i intuicji. Oczywiście można wszechstronnie, doskonale wręcz z formalnego punktu widzenia, przygotować nauczyciela-profesjonalistę w swojej dziedzinie, kompetentnego i wyposażonego w niezbędne umiejętności praktyczne, czy jednak nie istnieje wówczas niebezpieczeństwo, że będzie on automatycznie, mechanicznie, choć w sposób właściwy i nienaganny

\footnotetext{
Stownik jezzyka polskiego, red. M. Szymczak, PWN, Warszawa 1979, s. 997.

2 Tamże.

3 Tamże, s. 398.

4 Tamże, s. 307.
} 
realizować powierzone zadania dydaktyczno-wychowawcze, terapeutyczne i opiekuńcze.

„Profesja, zdaniem B. D. Gołębniak, w tradycyjnym tego słowa znaczeniu, oznacza ten rodzaj (dziedzinę) praktyki, która ma bardziej charakter służby dla publicznego dobra niż zajmowania się czymś (jakimś przedmiotem), głównie ze względu na wymierne, materialne korzyści (osobiste profity)" ${ }^{2}$. D. Fish ${ }^{6}$ przedstawia kilka możliwych, wzajemnie się uzupełniających oraz nierozerwalnie ze sobą korelujących wersji rozumienia stwierdzenia „być profesjonalistą":

"- Być profesjonalistą to znaczy być ekspertem know-how i to na bazie wiedzy teoretycznej - na magisterskim lub ekwiwalentnym poziomie. Aby zostać członkiem danej profesji, nie wystarczy jednak okazać się dyplomem ukończenia studiów akademickich. Wejście w większość tradycyjnych profesji wymaga uzyskania akceptacji i aprobaty, wyrażonej przez gremium składające się z przedstawicieli danej profesji. Nadanie profesjonalnego statusu następuje najczęściej w wyniku egzaminu (...). Od kandydata wymaga się nie tyle mistrzostwa, ujętego $\mathrm{w}$ kategoriach demonstrowanych wyników kształcenia, ile kompetencji w zakresie profesjonalnego osądu.

- Być profesjonalistą to znaczy dbać o utrzymanie osobistych standardów w zakresie wiedzy - teoretycznej i praktycznej, a także zachowywać wymaganą dyscyplinę i etyczność w zachowaniu wobec klientów (...).

- Być profesjonalistą to znaczy demonstrować działania, które są nie tylko efektowne, ale i zgodne $\mathrm{z}$ tradycją danej profesji. Centrum tej tradycji stanowi, dziś już może niemodny, koncept służby. Autonomia profesjonalisty i moralny wymiar jego praktyki polega na takim poruszaniu się wewnątrz profesjonalnych parametrów, które uwzględnia »rozważny użytek « $\mathrm{z}$ dokonania profesjonalnego osądu"7.

5 B. D. Gołębniak, Zmiany edukacji nauczycieli. Wiedza - biegtość - refleksyjność, Wydawnictwo EDYTOR, Toruń-Poznań 1998, s. 114.

6 Tamże.

7 Tamże, s. 115. 
Przedstawione wyżej refleksje skłaniają do wniosku, że nauczyciel/pedagog-profesjonalista to osoba przejawiająca cechy wielkiego humanitaryzmu w swoich postawach wobec wszystkich ludzi, w tym też niewątpliwie swoich podopiecznych, ich rodziców/opiekunów, wobec każdego obcego człowieka, nawet przypadkowo spotkanego na ulicy. To osoba posiadająca szeroką i dogłębną wiedzę na temat wykonywanej profesji, operująca na wysokim poziomie doskonałości i efektywności szerokim wachlarzem umiejętności praktycznych, chcąca i potrafiąca współpracować z profesjonalistami ze swojej dziedziny czy dyscyplin pokrewnych, dzieląca się własnymi osiągnięciami, doświadczeniami, sukcesami i porażkami. To także osoba faktycznie zaangażowana w pracę, poszukująca w swojej pracy nowych, bardziej doskonałych rozwiązań, refleksyjna i podająca w wątpliwość własną praktykę, odczuwająca wewnętrzne zobowiązanie do stałego testowania siebie, posiadanej wiedzy teoretycznej i kompetencji praktycznych. To również osoba zdolna do refleksji nad sobą, swoim życiem, pracą i własną, częstokroć subiektywną, oceną uzyskiwanych rezultatów, zdolna do porównywania oczekiwań, zamiarów stawianych wobec siebie z rzeczywistymi osiągnięciami oraz do wnioskowania nad tym, czy idealne udało się połączyć z realnym.

Sam, choćby najbardziej doskonale opanowany, warsztat zawodu nauczyciela bez predyspozycji wewnętrznych i powołania do zawodu nie zapewni bycia $\mathrm{w}$ tym zawodzie utalentowanym, kreatywnym i innowacyjnym „pedagogiem-artystą”. Nie przyczyni się do prawdziwego, płynącego z powołania uprawiania sztuki nauczania innych w sposób profesjonalny i kompetentny. Niewielu jest artystów w gronie aktorów zyskujących sławę i powszechny rozgłos w sztuce filmowej czy teatralnej lub wybitnych kompozytorów, malarzy, którzy przy doskonałym, perfekcyjnym opanowaniu technik profesjonalnych osiągnęli imponujące sukcesy zawodowe, sławę i podziw społeczny. I tak też niewielu może być artystów w edukacji, bez szczególnych uzdolnień w płaszczyźnie nauczania i wychowania. Jeśli nawet uda się komuś opanować techniki edukacyjno-terapeutyczno-rehabilitacyjne bez tego wyjątkowego, z rzeczywistej natury płynącego głosu powołania, wówczas istnieje bardzo duże niebezpieczeństwo, że uprawiać się będzie swój zawód, tworząc tzw. „niepełny artyzm”, lub nawet „pseudoar- 
tyzm", który tylko z pozoru będzie przypominał sztukę, prawdziwą sztuką nie będąc.

Holistyczne ujęcie kompetencji pracy nauczycielskiej nakazuje umiejscowienie $\mathrm{w}$ jej obszarze szerokiej wiedzy z dziedziny wykonywanego zawodu i dziedzin pokrewnych, umiejętności realizacji, w miarę możliwości, efektywnych działań praktycznych w sensie diagnostycznym, pragmatycznym i ewaluacyjnym, osobistej świadomości moralnej, cech osobowych i predyspozycji wrodzonych, bez których praca może stracić i na ogół traci swój sens, doprowadza do zawodowego i osobistego wypalenia, zamazania istoty tego, co się robi, w jaki sposób, dla kogo, dlaczego się to robi i w jakim celu, oraz do zagubienia siebie i w sobie.

Praca dydaktyczno-wychowawcza z osobami niepełnosprawnymi, ze względu na jej terapeutyczny charakter, wymaga specjalnych predyspozycji, wyjątkowych kompetencji i szczególnego profesjonalizmu. Złożoność osobowości ludzi niepełnosprawnych, specyfika ich rozwoju i może nie tyle specjalne, ile odmienne, a nawet szczególne, w kwestii zakresu, sposobów realizacji i form oddziaływań potrzeby edukacyjne sprawiają, że osoby takie potrzebują więcej ciepła, serdeczności i zrozumienia. Nie mniej ciepła, serdeczności, zrozumienia potrzebuje także najbliższe otoczenie dziecka niepełnosprawnego - jego rodzice, rodzeństwo.

Specjaliści pracujący z uczniem niepełnosprawnym, z racji podmiotu swoich oddziaływań, powinni mieć wyjątkowe predyspozycje, rozległą wiedzę, obejmującą różne obszary pedagogiki specjalnej, szczególne umiejętności i dużą intuicję. Na gruncie pedagogiki specjalnej do dnia dzisiejszego musimy i powinniśmy korzystać z intuicji i kreatywności w odkrywaniu novum. P. Bosmans pisze: „Od czasu do czasu musisz uczyć się latać »na ślepo«, jak piloci we mgle”. Bowiem $\mathrm{w}$ pracy pedagoga pracującego $\mathrm{z}$ uczniem niepełnosprawnym pojawia się potrzeba uwzględnienia nie tylko wiedzy, sprawdzonych już w życiu teorii rozwoju człowieka i ogólnie przyjętych zasad postępowania, ale także słuchania „wewnętrznego głosu”, który naka-

8 P. Bosmans, Być człowiekiem, Wydawnictwo Salezjańskie, Warszawa 1996, S. 24. 
zuje nieraz postąpić lub działać wbrew powszechnie zaakceptowanym procedurom. D. Kocydłowska, analizując doświadczenia własne w zakresie wspomagania rozwoju dzieci niepełnosprawnych, zauważa: „Niejednokrotnie stawałam przed próbą rozwiązania problemów, o których nic nie zostało napisane w podręcznikach. Polegałam wtedy na własnej intuicji”".

Zadania pedagoga specjalnego w procesie edukacji i rehabilitacji dziecka niepełnosprawnego można postrzegać na continuum diagnoza-terapia-wspomaganie rozwoju oraz wspomaganie jego rodziny. Jeśli dzięki kompetentnej, profesjonalnej i refleksyjnej pracy pedagog specjalny osiąga zamierzone rezultaty w postaci postępów rozwojowych dziecka na miarę jego indywidualnych możliwości, wtedy pojawia się zadowolenie i satysfakcja. Jednak prawdziwe zadowolenie z wykonywanych obowiązków zawodowych może powstać tylko wówczas, kiedy pedagog specjalny dysponuje wewnętrznymi predyspozycjami do bycia nim w całej okazałości, tj. w połączeniu z właściwymi kompetencjami i profesjonalizmem. W takiej sytuacji łatwiej jest też przeżywać różne porażki, w tym też porażki zawodowe, i przeciwdziałać zjawisku wypalenia zawodowego.

Powołanego do pracy z osobami niepełnosprawnymi specjalistę powinno charakteryzować również człowieczeństwo, które polega na okazywaniu miłości podopiecznym, życzliwości, zrozumienia, bliskości, na dzieleniu się radością i fascynacji z kontaktu z takimi osobami. Żaden bowiem człowiek nie może rozwijać się należycie bez wzajemnych kontaktów z innym człowiekiem. Podstawą tych kontaktów jest przecież szacunek i miłość. „Młody ptak wyrzucony z gniazda, umiera. Dziecko, które nie doznało uścisku miłości, »zamarza«. Człowiek, by stać się człowiekiem, potrzebuje ciepła i miłości”10. „W każdym człowieku - pisze P. Bosmans - można podziwiać nie tylko to, co u niego dostrzegalne i dotykalne, ale przede wszystkim ową tajemnicę, ukrytą

\footnotetext{
9 D. Kocydłowska, Z doświadczeń terapeuty. Refleksje optymistyczne, w: Człowiek wobec ograniczeń. Niepetnosprawność, komunikacja, diagnoza, terapia, red. Z. Tarkowski, G. Jastrzębowska, Wydawnictwo Fundacji ORATOR, Lublin 2002, s. 338.
}

$10 \quad$ P. Bosmans, dz. cyt., s. 59. 
w »opakowaniu« ludzkiego ciała, która czasem zdaje się być tak bliska, a w istocie jest ona daleka"11.

Badania naukowe mające na celu poznanie opinii rodziców dzieci głuchoniewidomych na temat cech oraz postępowania specjalistów realizujących działalność edukacyjno-rehabilitacyjną z daną kategorią osób niepełnosprawnych dowodzą, że najwyżej cenione są, poza wykształceniem, kompetencjami zawodowymi i profesjonalizmem (wiedza teoretyczna, operowanie metodami wspomagającymi rozwój dziecka, znajomość alternatywnych sposobów komunikacji), predyspozycje osobowościowe i czysto „ludzkie” zachowania: cierpliwość, wyrozumiałość, życzliwość, dobroć, serdeczność, otwartość, opanowanie, miłość do dziecka, kreatywność, wrażliwość, powołanie, poświęcenie, bezinteresowność, obiektywizm, tolerancja, sumienność, uczciwośćc ${ }^{12}$.

\section{ZAKOŃCZENIE}

Konkludując, należy zauważyć, że pedagog specjalny to człowiek specjalny, szczególny - zarówno jeśli chodzi o predyspozycje profesjonalne, zawód, jaki wykonuje, jak i o cechy osobowościowe, które powinien posiadać. Na czym więc polega specjalność zawodu pedagoga specjalnego, a na czym specjalność jego osobowości?

Odpowiadając na pytanie pierwsze - najogólniej rzecz ujmując - można powiedzieć, że specjalność pedagoga specjalnego polega przede wszystkim na specyfice jego działalności pedagogicznej. Specyfika ta wyrażona jest między innymi: specjalnymi warunkami realizacji podejmowanych działań, specjalnymi celami i zadaniami edukacji czy wykorzystywaniem specjalnych metod stymulacji rozwoju swoich podopiecznych. Jednakże zasadniczo o specjalności pracy pedagoga

\footnotetext{
11 Tamże, s. 8.

12 M. Zaorska, Nauczyciel - wychowawca - terapeuta dziecka z zaburzeniami złożonymi w opinii rodziców dzieci z głuchoślepota wrodzona, w: Nauki pedagogiczne $w$ teorii i praktyce edukacyjnej, t. 1, red. J. Kuźma i J. Morbitzer, Wydawnictwo Akademii Pedagogicznej, Kraków 2003.
} 
specjalnego decyduje wyjątkowy podmiot oddziaływań pedagogicznych - osoba niepełnosprawna, tj. osoba, która potrzebuje, wymaga i oczekuje wyjątkowego traktowania, wyjątkowego wsparcia, wyjątkowego zrozumienia problemów, z którymi się styka, a które to problemy są konsekwencją ograniczeń organicznych i nie mniejszych ograniczeń o charakterze mentalnym, wynikających z różnorodnych i niestety jeszcze dość często neutralnych lub nawet negatywnych nastawień społeczeństwa do środowiska osób niepełnosprawnych.

Co do kwestii specjalności osobowości pedagoga specjalnego warto i należy wskazać pewne elementy/cechy, które decydują i/lub mogą decydować o podejściu do pracy, o percepcji jej istoty oraz jakości działań pedagogicznych realizowanych wobec osoby z niepełnosprawnością: otwartość na problemy innego człowieka, życzliwość i zrozumienie jego problemów, szacunek we wzajemnych kontaktach, dobroć, serdeczność, refleksyjność nad postępowaniem czy zachowaniem drugiej osoby i własnym, świadomość ograniczoności posiadanej przez siebie wiedzy, umiejętności, możliwości i świadomość, że nie ma ludzi nieomylnych. Każdy z nas - dziecko z niepełnosprawnością, członkowie jego rodziny, inni specjaliści - może i ma prawo, gdzieś czy kiedyś (oby nie za często) i nie ze złej woli, pomylić się i jest to rzecz normalna, właściwa istocie ludzkiej.

Tadeusz Gałkowski podkreśla, że dobry terapeuta to człowiek z pasją. „Dopóki ma pasję, jest skuteczny. Kiedy skończy się pasja, niech już tylko dzieli się swoim doświadczeniem z innymi (...)"13.

\section{Summary}

The Role and Place of the Special Educator in CREATing EdUCATIONAL AND Therapeutic Activities

The profession of a special educator is among the specific and exceptional ones due to the recipient of their tasks. This is in fact addressed to a person with a disability, which means that it needs and expects a rational and deliberately targeted professional help. Therefore, from a special educator

13 Cyt. za: D. Kocydłowska, dz. cyt., s. 340. 
it is required not only a broad and interdisciplinary knowledge, numerous professional competence, but also, and above all personality predisposition and the presence of creativity and innovation in the ongoing educational and therapeutic activities. In this article there are presented the reflections of presenting the essence of the social work and mission of a today's special educators. 